\title{
Simulation and Cost Optimization of different Heat Exchangers for $\mathrm{CO}_{2}$ Capture
}

\author{
Solomon Aforkoghene Aromada ${ }^{1}$, Nils Henrik Eldrup ${ }^{1,2}$, Fredrik Normann $^{3}$, Lars Erik $\emptyset_{i^{1}}$ \\ ${ }^{1}$ Department of Process, Energy and Environmental Technology, University of South-Eastern Norway \\ ${ }^{2}$ SINTEF Tel-Tek, SINTEF Industri, Kjølnes Ring 30, 3918, Porsgrunn, Norway \\ ${ }^{3}$ Chalmers University of Technology, 412 96, Göteborg, Sweden \\ Corresponding author’s email address: solomon.a.aromada@usn.no; saromada@gmail.com
}

\begin{abstract}
The industrial deployment of amine-based $\mathrm{CO}_{2}$ capture technology requires large investments as well as extensive energy supply for desorption. Therefore, the need for efficient cost and economic analysis aimed at $\mathrm{CO}_{2}$ capture investment and operating costs is imperative. Aspen HYSYS simulations of an $85 \% \quad \mathrm{CO}_{2}$ absorption and desorption process for flue gas from cement industry, followed by cost estimation have been performed. This is to study the cost implications of different plants options. Each plant option has a different lean/rich heat exchanger type. Cost optimisation of the different heat exchangers is also done in this work. Three different shell and tube and two plate and frame heat exchangers have been examined. The minimum $\mathrm{CO}_{2}$ capture cost of $€ 57.9 /$ ton $\mathrm{CO}_{2}$ is obtained for a capture plant option having a gasketed-plate heat exchanger with $\Delta T_{\min }$ of $5{ }^{\circ} \mathrm{C}$ as the lean/rich heat exchanger. The use of plate and frame heat exchangers will result in considerable $\mathrm{CO}_{2}$ capture cost reduction.
\end{abstract}

Key words: simulation, CO2, CCS, heat exchanger, shell and tube, Aspen HYSYS, plate heat exchanger

\section{Introduction}

There has been increased public concern for mitigation of global warming, which is largely caused by emissions of carbon dioxide $\left(\mathrm{CO}_{2}\right)$. Carbon capture and storage (CCS) is generally recognised as an urgent mitigation measure (Rubin et al., 2013). The amine-based post-combustion $\mathrm{CO}_{2}$ capture technology is the most matured and promising technology option (Nwaoha, 2018). However, its industrial deployment requires large investments as well as enormous energy supply for desorption (Lim et al., 2013; Aromada and Øi, 2017). Therefore, the need for efficient cost and economic analysis aimed at reduced $\mathrm{CO}_{2}$ capture investment and operating costs is imperative.

The lean/rich heat exchanger is one of the most expensive equipment in an amine-based $\mathrm{CO}_{2}$ capture plant, and it has a considerable cost implication on the investment (Ali et al., 2019).

In preliminary cost estimation of heat exchangers, the important design parameter is the heat transfer area needed. That is evaluated from the heat duty (heat transfer from hot to cold stream), overall heat transfer coefficient, and the log-mean temperature difference (LMTD) (van der Spek et al., 2019). However, the required heat duty depends on the minimum approach temperature $\left(\Delta T_{\min }\right)$.

In post-combustion solvent-based $\mathrm{CO}_{2}$ capture, studies on cost optimisation of the lean/rich MEA heat exchanger have been based on $\Delta T_{\min }$ of the shell and tube heat exchanger (STHX) types (Kallevik, 2010; Øi et al., 2014; Aromada and Øi, 2017; Ali et al., 2019). None of such studies has been found for the plate and frame heat exchanger (PHE). Thus, this study is conducted on cost optimisation of the PHE based on $\Delta T_{\min }$. This is carried out by performing process simulations of $\mathrm{CO}_{2}$ absorption and desorption process. Cost estimation and optimisation to find the most cost effective and technically suitable type of heat exchanger for the lean/rich heat exchanger is then carried out.

\subsection{Process Description and Scope}

The process comprises a flue gas fan for transporting the flue gas through the direct contact cooler (DCC) where the temperature is reduced. The DCC pump and DCC cooler help in circulation and cooling of the water respectively. The main capture process consists of an absorber, a desorber with a reboiler at the bottom and a condenser, lean/rich heat exchanger, pumps and a cooler. Figure 1 shows the flowsheet of the standard capture process. 


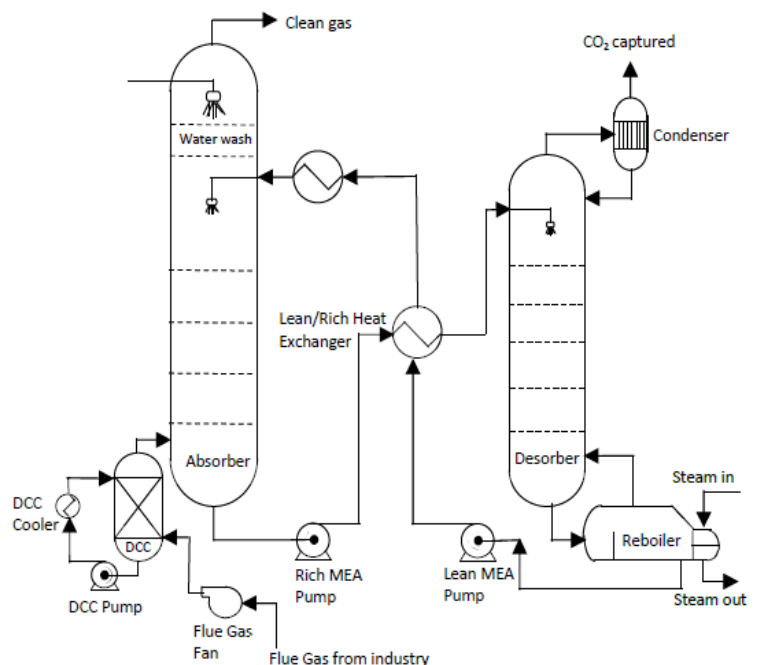

Figure 1. . Flowsheet of the standard process

\section{Simulation, Specifications and Assumptions}

\subsection{Specifications for Simulation}

Table 1 presents the specifications used for the base case simulations. The flue gas data are from a cement industry and are taken from (Onarheim et al., 2015; Ali et al., 2019).

\subsection{Process Simulation}

Aspen HYSYS Version 10 is used for the simulations with the same calculation approach as in (Øi, 2007; Aromada and Øi, 2015). The difference is that in version 10 , the acid gas property package replaces the Amine property package in previous versions.

Table 1. Specifications for simulation (Onarheim et al., 2015; Ali et al., 2019)

\begin{tabular}{|c|c|}
\hline \\
\hline \multicolumn{2}{|l|}{ Flue gas } \\
\hline Temperature $\left[{ }^{\circ} \mathrm{C}\right]$ & 80 \\
\hline Pressure $[\mathrm{kPa}]$ & 121 \\
\hline $\mathrm{CO}_{2}$ mole-fraction & 0.2520 \\
\hline $\mathrm{H}_{2} \mathrm{O}$ mole-fraction & 0.0910 \\
\hline $\mathrm{N}_{2}$ mole-fraction & 0.5865 \\
\hline $\mathrm{O}_{2}$ mole-fraction & 0.0705 \\
\hline Molar flow rate $[\mathrm{kmol} / \mathrm{h}]$ & 11472 \\
\hline \multicolumn{2}{|l|}{ Flue gas from from DCC to absorber } \\
\hline Temperature $\left[{ }^{\circ} \mathrm{C}\right]$ & 40 \\
\hline Pressure $[\mathrm{kPa}]$ & 121 \\
\hline \multicolumn{2}{|l|}{ Lean MEA } \\
\hline Temperature & 40 \\
\hline Pressure $[\mathrm{kPa}]$ & 121 \\
\hline Molar flow rate $[\mathrm{kmol} / \mathrm{h}]$ & 96850 \\
\hline Mass fraction of MEA [\%] & 29 \\
\hline Mass fraction of $\mathrm{CO}_{2}[\%]$ & 5.30 \\
\hline \multicolumn{2}{|l|}{ Absorber } \\
\hline No. of absorber stages & 15 \\
\hline Absorber Murphree efficiency [\%] & $11-21$ \\
\hline$\Delta T_{\min }$, lean/rich heat exchanger $\left[{ }^{\circ} \mathrm{C}\right]$ & 10 \\
\hline \multicolumn{2}{|l|}{ Desorber } \\
\hline Number of stages & 10 \\
\hline Desorber Murphree efficiency [\%] & 100 \\
\hline Pressure $[\mathrm{kPa}]$ & 200 \\
\hline Reboiler temperature $\left[{ }^{\circ} \mathrm{C}\right]$ & 120 \\
\hline Reflux ratio in the desorber & 0.3 \\
\hline Temperature into desorber $\left[{ }^{\circ} \mathrm{C}\right]$ & 104.6 \\
\hline
\end{tabular}

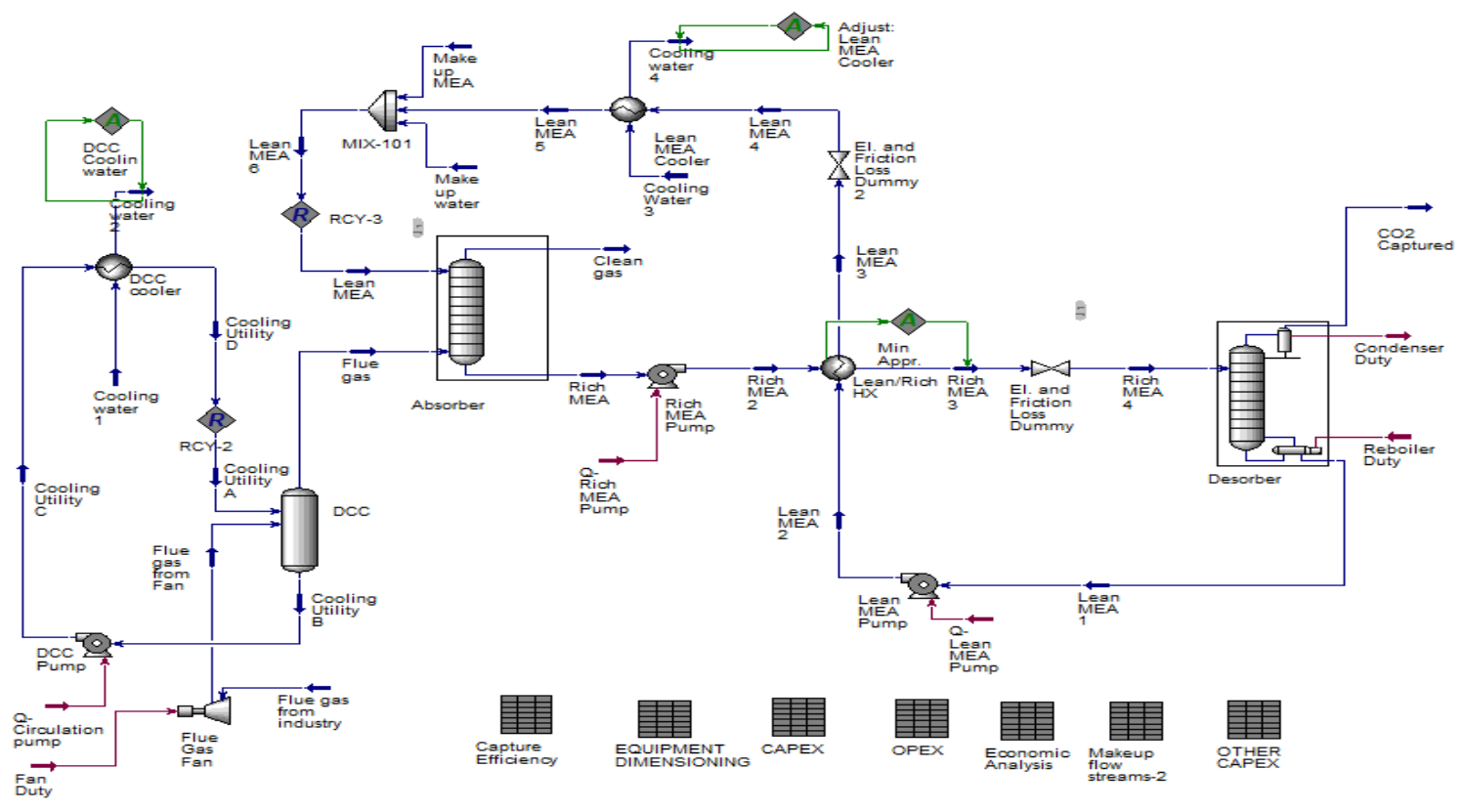

Figure 2. Aspen HYSYS flowsheet 
The absorption column as well as the desorption columns are both simulated as equilibrium stages with stage efficiencies. The absorber is simulated with 15 packing stages, while it is 10 packing stages for the desorber. Murphree efficiencies for $\mathrm{CO}_{2}$ are specified in the simulation. For more details on Murphree efficiency, see (Øi, 2007). Equilibrium stages of $1 \mathrm{~m}$ height each for both columns are assumed. Murphree efficiencies of $11-21 \%$ were specified from bottom to the top of the absorption column (Ali et al., 2019). A constant Murphree efficiency of $100 \%$ is specified for all the stages of the desorption column. The Modified HYSIM Inside-Out algorithm was selected in the columns because it helps to improve convergence (Aromada and $\left.\emptyset_{i}, 2015\right)$.

Adiabatic efficiency of $75 \%$ was specified for all the pumps and the flue gas fan. The Aspen HYSYS simulation process flow diagram (PFD) is given in Figure 2.

\section{Methods}

\subsection{Scope of the Cost Estimates}

The equipment included in this cost analysis are for cooling the flue gas before it enters the absorption column, and for the absorption and desorption process as can be seen in Figure 1 and Figure 2. The study does not include equipment for pre-treatment unit of the flue gas and water-wash section. The equipment for $\mathrm{CO}_{2}$ compression are not considered because the focus is on the lean/rich heat exchanger

The total investment cost in this study is limited to the sum of the installed costs of the equipment considered. The cost of acquiring the site (land), preparing the site and for service buildings are not included.

The operating and maintenance costs (OPEX) include the cost of electricity, steam, cooling and process water, solvent (MEA), salaries of 6 operators and 1 engineer, and annual maintenance cost set at $4 \%$ of the installed cost of the equipment as given in Table 2.

Table 2. Operating cost data

\begin{tabular}{|c|c|c|c|}
\hline & Unit & Value/unit* & Reference \\
\hline Steam & $€ / \mathrm{kWh}$ & 0.032 & $\begin{array}{l}\text { Husebye et al. } \\
\text { (2012) }\end{array}$ \\
\hline Electricity & $€ / \mathrm{kWh}$ & 0.132 & Ali et al. (2019) \\
\hline Water & $€ / \mathrm{m}^{3}$ & 0.022 & Ali et al. (2019) \\
\hline MEA & $€ / \mathrm{m}^{3}$ & 2069 & Ali et al. (2019) \\
\hline Maintenance & $€$ & $\begin{array}{l}4 \% \text { of } \\
\text { CAPEX }\end{array}$ & Ali et al. (2019) \\
\hline Operator & $€$ & $85350(x 6)$ & Ali et al. (2019) \\
\hline Engineer & $€$ & 166400 & Ali et al. (2019) \\
\hline
\end{tabular}

Costs for $\mathrm{CO}_{2}$ transport and storage, preproduction costs, insurance, taxes, first fill cost and administrative costs are not included in the OPEX.

\subsection{Equipment Dimensioning and Assumptions}

Dimensioning of equipment in this study follows the approach used in Ali et al. (2019) based on mass conservation and energy balances of the system. Table 3 summarises the dimensioning factors and assumptions used in this work.

Table 3. Equipment dimensioning factors and assumptions

\begin{tabular}{|c|c|c|}
\hline Equipment & $\begin{array}{l}\text { Sizing } \\
\text { factors }\end{array}$ & Basis/Assumptions \\
\hline DCC Unit & \multirow{3}{*}{$\begin{array}{l}\text { Tangent- } \\
\text { to- } \\
\text { tangent } \\
\text { height } \\
\text { (TT), } \\
\text { Packing } \\
\text { height, } \\
\text { internal } \\
\text { and } \\
\text { external } \\
\text { diameters } \\
\text { (all in } \\
\text { [m]) }\end{array}$} & $\begin{array}{l}\text { Velocity using Souders- } \\
\text { Brown equation with a k- } \\
\text { factor of } 0.15 \mathrm{~m} / \mathrm{s}(\mathrm{Yu}, \\
2014, \mathrm{pp} .97) . \mathrm{TT}=15 \mathrm{~m}, 1 \\
\mathrm{~m} \text { packing height/stage (4 } \\
\text { stages) }\end{array}$ \\
\hline Absorber & & $\begin{array}{l}\text { Superficial velocity of } 2 \\
\mathrm{~m} / \mathrm{s}, \mathrm{TT}=40 \mathrm{~m}, 1 \mathrm{~m} \text { packing } \\
\text { height/stage ( } 15 \text { stages) }\end{array}$ \\
\hline Desorber & & $\begin{array}{l}\text { Superficial velocity of } 2 \\
\mathrm{~m} / \mathrm{s}, \mathrm{TT}=22 \mathrm{~m}, 1 \mathrm{~m} \text { packing } \\
\text { height/stage (10 stages) }\end{array}$ \\
\hline $\begin{array}{l}\text { Lean/rich } \\
\text { heat } \\
\text { exchanger }\end{array}$ & \multirow{4}{*}{$\begin{array}{l}\text { Heat } \\
\text { transfer } \\
\text { area, A } \\
{\left[\mathrm{m}^{2}\right]}\end{array}$} & $\begin{array}{l}\mathrm{U}=0.5 \mathrm{~kW} / \mathrm{m}^{2} . \mathrm{K} \text { (Ali et al., } \\
2019)\end{array}$ \\
\hline Reboiler & & $\begin{array}{l}\mathrm{U}=0.8 \mathrm{~kW} / \mathrm{m}^{2} . \mathrm{K} \text { (Ali et al., } \\
2019)\end{array}$ \\
\hline Condenser & & $\begin{array}{l}\mathrm{U}=1.0 \mathrm{~kW} / \mathrm{m}^{2} . \mathrm{K} \text { (Ali et al., } \\
2019)\end{array}$ \\
\hline Coolers & & $\begin{array}{l}\mathrm{U}=0.8 \mathrm{~kW} / \mathrm{m}^{2} . \mathrm{K} \text { (Ali et al., } \\
2019)\end{array}$ \\
\hline Pumps & $\begin{array}{l}\text { Flow rate } \\
{[1 / \mathrm{s}]}\end{array}$ & Centrifugal \\
\hline $\begin{array}{l}\text { Flue gas } \\
\text { fans }\end{array}$ & $\begin{array}{l}\text { Flow rate } \\
{\left[\mathrm{m}^{3} / \mathrm{h}\right]}\end{array}$ & Centrifugal \\
\hline
\end{tabular}

\subsection{Cost Estimation and Assumptions}

The Enhanced Detailed Factor (EDF) method is used for estimation of all the equipment costs and overall plant investment cost. Readers are referred to Ali et al. (2019) for the details and application of the EDF method.

The purchased costs of the equipment are obtained from Aspen In-plant Cost Estimator Version 11 with a cost year of 2018 (January). The costs are then escalated to January 2020 using the SSB (Norwegian Statistisk sentralbyrå, webpage) 
industrial cost index $(2018=106 ; 2020=111.3)$. The currency conversion rate for Euro to NOK is 10.13, taken from (NorgesBank, 2020 webpage) on January 25, 2020. Conversion to NOK is necessary to use the enhanced factors developed by Nils Eldrup (Ali et al., 2019). The default location is Rotterdam in Netherlands.

All equipment is assumed to be made from stainless steel (SS316), except the Flue gas fan, which is from carbon steel (CS). Material factor to convert costs in SS316 to CS is 1.75 and 1.30 for seamless and welded equipment respectively.

A brownfield, and an Nth-of-a-kind (NOAK) project are assumed. 25 years of project, of which 2 years are for plant construction, and $7.5 \%$ interest rate is also assumed (Ali et al., 2019).

\section{Results and Discussion}

\subsection{Simulation Results}

Table 4 presents the process simulation results for the base case and sensitivity analysis of $\Delta T_{\text {min }}$. Lower $\Delta T_{\min }$ give lower reboiler heat and lower lean MEA cooler duty (more heat has been transferred from the lean stream to the rich stream). Therefore, less steam and less cooling water are required in the reboiler and lean MEA cooler respectively.

Table 4. Simulation results

\begin{tabular}{cccc}
\hline $\begin{array}{c}\Delta \mathrm{T}_{\min } \\
{\left[{ }^{\circ} \mathrm{C}\right]}\end{array}$ & $\begin{array}{c}\text { Reboiler } \\
\text { heat } \\
{[\mathrm{GJ} / \text { ton }}\end{array}$ & $\begin{array}{c}\text { Typical } \\
\text { results }\end{array}$ & $\begin{array}{c}\text { Lean MEA } \\
\text { cooler duty } \\
{[\mathrm{kW}]}\end{array}$ \\
\hline 5 & 3.83 & & 66389 \\
10 & 4.08 & $3.3-5.0$ & 81333 \\
15 & 4.27 & $($ Nwaoha & 89333 \\
20 & 4.67 & et al.,2018) & 117778 \\
\hline
\end{tabular}

\subsection{Base Case Plant Investment Cost}

The base case in this study has a U-tube shell and tube heat exchanger. The total investment cost (CAPEX) which is the sum of the installed costs of all the equipment is $€ 97.5$ million. The cost estimation results obtained show the same trends with similar studies by Ali et al. (2018) and Ali et al. (2019). The lean/rich heat exchanger contributes most to the total investment cost compared to other equipment as in Figure 3.

The heat exchanger accounts for $41 \%$ of the total capital cost (Figure 4). Ali et al. (2019) also calculated the lean/rich heat exchanger to have the highest installed cost for the same scope as in this study. It accounts for $37 \%$ of the $\mathrm{CO}_{2}$ capture plant. They obtained their cost data from Aspen In-plant Cost Estimator V10 with a cost data year of 2016.
Aspen In-plant Cost Estimator V11 with a cost data year 2018 is used in this study. In addition, the cost in this study are escalated from 2018 to 2020 . This explain the $3 \%$ difference from a similar process. In the work of Nwaoha et al. (2018), for a process with an absorber packing height and diameter of $21.95 \mathrm{~m}$ and $10.07 \mathrm{~m}$ respectively, the lean/rich heat exchanger has the second highest cost for both MEA and AMP-PZ-MEA systems. The absorber in their case has the highest cost. The diameter is almost twice and the packing height is approximately $7 \mathrm{~m}$ higher than in this work. The study was for a $90 \% \mathrm{CO}_{2}$ capture process from a cement plant flue gas with 0.115 mole of $\mathrm{CO}_{2}$. In this study, capture efficiency is $85 \%$ and the $\mathrm{CO}_{2}$ molar composition is 0.252 .

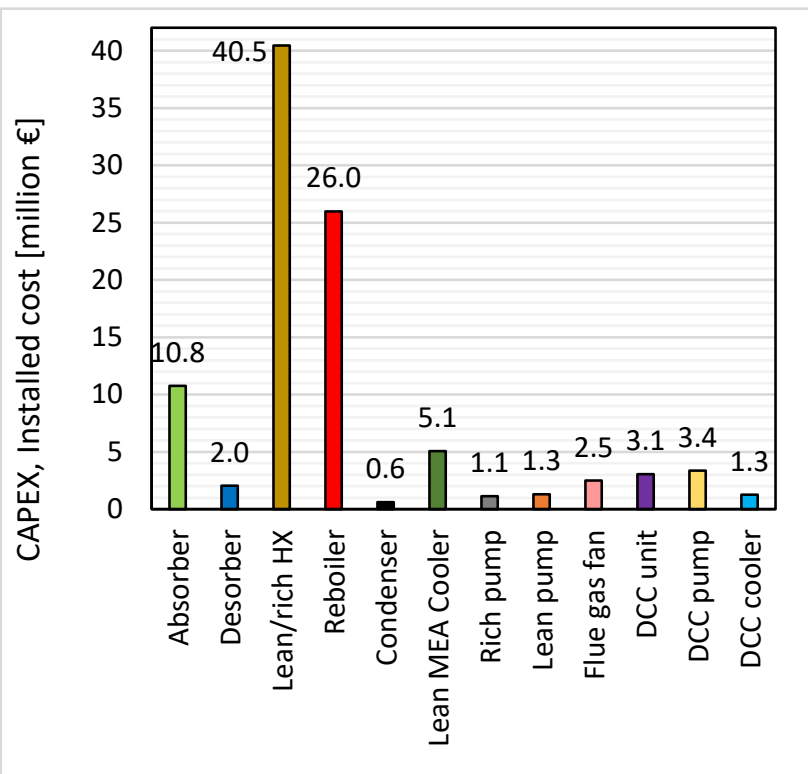

Figure 3. Equipment installed costs of the base case $85 \% \mathrm{CO}_{2}$ capture plant

\subsection{Operation and Maintenance Costs}

The annual operation and maintenance $(\mathrm{O} \& \mathrm{M})$ cost for the base case is $€ 44.5$ million. Only the steam consumption costs $€ 31.7$ million and annual maintenance cost is $€ 3.9$ million.

\subsection{Annualised CAPEX, Total Annual Cost and Capture Cost}

Annualised capital cost is obtained from the following relation:

Annualised CAPEX $=\frac{\text { CAPEX }}{\text { Annualised factor }}$

The annualised factor is calculated as follows: 


$$
\text { Annualised factor }=\sum_{i=1}^{23}\left[\frac{1}{(1+r)^{n}}\right]
$$

Where $n$ represents operational years and $r$ is discount/interest rate. The annualised CAPEX for the base case is evaluated to be $€ 9$ million $\left(\mathrm{CO}_{2}\right.$ compression equipment not included). Thus, the total annual cost, which is the sum of the annualised CAPEX and the yearly OPEX, is €53.6 million. Figures 4 presents the annual cost distribution. The $\mathrm{CO}_{2}$ capture cost is estimated from:

$$
\mathrm{CO}_{2} \text { capture cost }=\frac{\text { Total annual cost }}{\text { Mass of } \mathrm{CO}_{2} \text { Captured }}
$$

The $\mathrm{CO}_{2}$ capture cost for the base case is 61.9 $€ /$ ton $\mathrm{CO}_{2}$ (2020). In the literature, it is between $€ 50 /$ ton $\mathrm{CO}_{2}-128 /$ ton $\mathrm{CO}_{2}$ (Ali et al., 2019). (Ali et al., 2019) calculated this cost for a similar process but with the compression section to be $€ 62.5 /$ ton $\mathrm{CO}_{2}$ for a cost year of 2016 . For a full process that include compression, Nwaoha et al. (2018) calculated this cost for $90 \% \mathrm{CO}_{2}$ capture from a cement plant flue gas with $\mathrm{CO}_{2}$ compression to be US\$93.2/ton $\mathrm{CO}_{2}$ (i.e., €74.5/ton $\mathrm{CO}_{2}$ ). According to Irlam (2017), for a first-of-a-kind (FOAK) CSS complete technology, the $\mathrm{CO}_{2}$ avoided cost for the cement industry is US\$188 (€164.4) and US\$130 $(€ 113.7)$ per ton $\mathrm{CO}_{2}$ for Germany and Poland respectively. FOAK technologies usually cost between 15 - 55\% more than NOAK (Boldon \& Sabharwall, 2014).

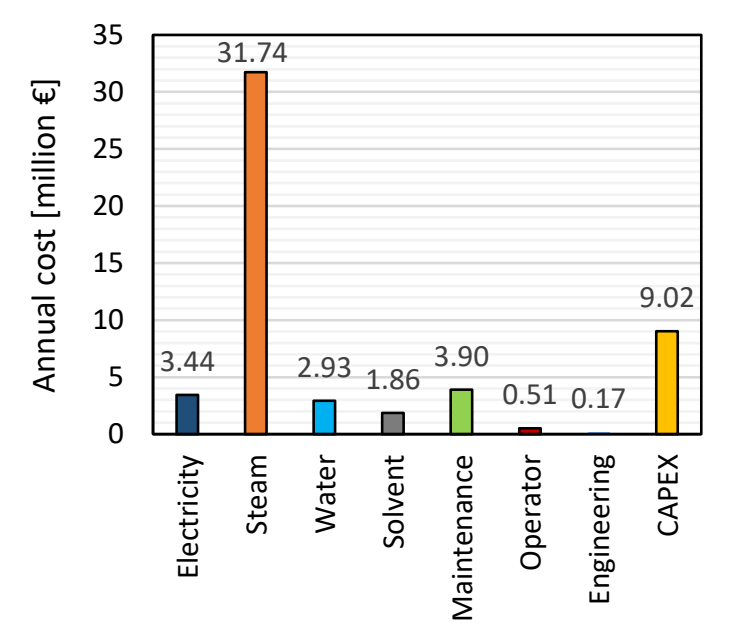

Figure 4. Cost distribution of the base case total annual cost

(Carbon Capture \& Storage Association, 20112020) states that the capture cost range is $€ 60 /$ ton $\mathrm{CO}_{2}-€ 90 /$ ton $\mathrm{CO}_{2}$ for the power industry. They projected that it will reduce considerably to $€ 35-$ $50 /$ ton $\mathrm{CO}_{2}$ in the beginning of 2020. Based on Figure 4, this reduction will have to come from reducing mainly the cost of steam. This can be achieved using available waste heat to generate steam or very cheap steam for desorption (Ali et al., 2018). Electricity cost is low in this study compared to Nwaoha et al. (2018) and Ali et al. (2019). This is because $\mathrm{CO}_{2}$ compression is not considered in this work. The compressors require much more electrical energy compared to pumps and fan/blower

\subsection{CAPEX Based on Different Heat Exchangers}

Figure 5 presents the total installed cost of $\mathrm{CO}_{2}$ capture plant options of using the different types of heat exchangers. The compact heat exchangers offer considerable lower total investment cost compared to the conventional shell and tube heat exchangers. Using the gasketed-plate heat exchanger (G-PHE) will give the lowest plant investment cost. The purchase cost of the welded-plate heat exchanger (W-PHE) was assumed to be $30 \%$ more expensive than the G-PHE based on information from Peters et al. (2004).

The reference case, which has U-tube shell and tube heat exchanger (UT-STHX) has investment cost of $€ 97.5$ million. The case with fixed tube sheet heat exchanger (FTS-STHX) has a CAPEX of $€ 102.4$ million. The installed cost of the plant with G-PHE is $€ 72.6$ million. The plant option with floating-head shell and tube heat exchanger (FHSTHX) gives the highest installed cost of $€ 103.8$ million.

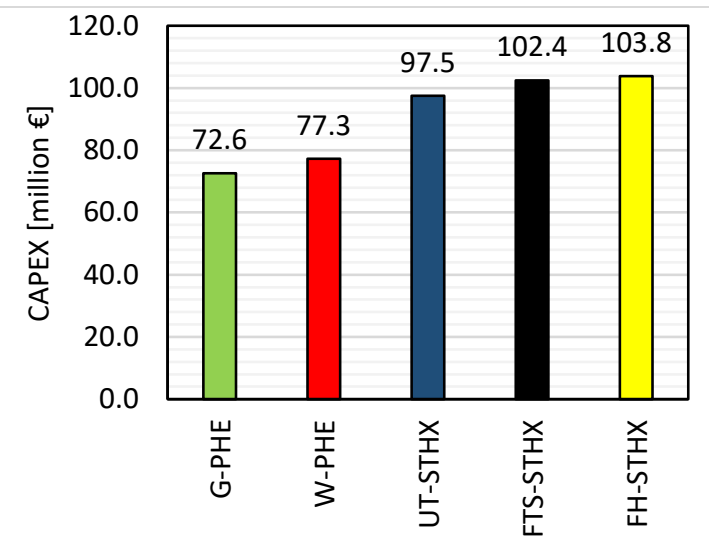

Capture plant with different heat exchanger

Figure 5. Total plant installed costs for different heat exchangers

\subsection{Optimisation: Minimum Approach Temperature}

Cost optimisation of the lean/rich heat exchanger in this study is done by finding the cost optimum minimum approach temperature $\left(\Delta T_{\min }\right)$.

The plants with G-PHE and welded-plate heat exchanger (W-PHE) have their minimum CAPEX 
at $15^{\circ} \mathrm{C}$, while it is $20^{\circ} \mathrm{C}$ for the 4 STHXs. As the $\Delta T_{\min }$ increases, the heat transfer area is reduced, thereby reducing the CAPEX since the lean/rich heat exchanger with STHXs account for $41-45 \%$ of the CAPEX in this study. The slight increase of CAPEX from $15-20^{\circ} \mathrm{C}$ as can be observed in Figure 6 for the PHEs is caused by increase in the cost of other equipment like the lean MEA cooler and the reboiler. This will also result in higher OPEX, especially from higher steam consumption as can be seen in Table 3 and Figure 7. More cooling water is also needed. However, increase in OPEX is slight from $5-15^{\circ} \mathrm{C}$ for the STHXs but becomes significantly steep from $15-20^{\circ} \mathrm{C}$. That is the same for the PHEs except that the OPEX is considerably lower at $5^{\circ} \mathrm{C}$ compared to $10^{\circ} \mathrm{C}$.

In order to find the optimum design $\Delta T_{\min }$ we evaluated the $\mathrm{CO}_{2}$ capture cost at the different $\Delta T_{\min }$ for the different heat exchanger options. Figure 8 presents the results.

The STHXs and W-PHE have their optimum $\mathrm{CO}_{2}$ capture costs at $15^{\circ} \mathrm{C}$. While the G-PHE optimum cost is at $5^{\circ} \mathrm{C}$, which is due to its relative lower cost per heat transfer area and lower maintenance cost. Cost savings of $€ 1.6 / \mathrm{tCO}_{2}$, $€ 1.1 / \mathrm{tCO}_{2}$ and $€ 1.0 / \mathrm{tCO}_{2}$ are achieved by the cost optimum cases with U-tube, fixed tube-sheets and floating-head shell and tube heat exchangers when compared with the base case. The cost optimum cases with gasketed and welded plate heat exchangers have a cost savings of $€ 4.0 / \mathrm{tCO}_{2}$ and $€ 3.4 / \mathrm{tCO}_{2}$ respectively.

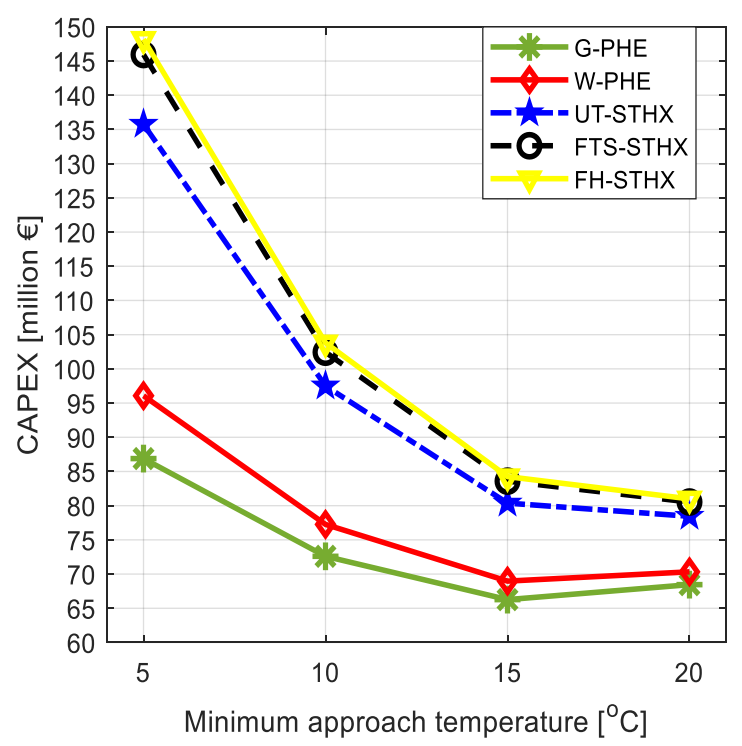

Figure 6. CAPEX of the different heat exchangers at different $\Delta T_{\min }$

All the studies of optimum $\Delta T_{\min }$ we found of solvent-based $\mathrm{CO}_{2}$ capture used STHXs (Kallevik, 2010; Øi et al. (2014), Li et al., 2016; Aromada \& Øi, 2017; Nwaoha et al., 2018; Ali et al., 2019). None of such studies was found for other types of heat exchangers like PHE. This is because in the chemical industry, about $60 \%$ of heat exchangers in use are STHX (Peters et al., 2004). They are more robust, they can be applied in all types of processes, they can withstand higher pressures, higher temperatures and thermal stresses, and higher pressure difference between the hot and cold streams.

Additional advantage of the STHX is that they have well-established design codes, standards and specifications, especially by TEMA (Tubular Exchanger Manufacturers Association) and American Society for Mechanical Engineers (ASME). The PHEs do not have such established or accepted design standards. Therefore, higher design uncertainties are expected for the PHEs.

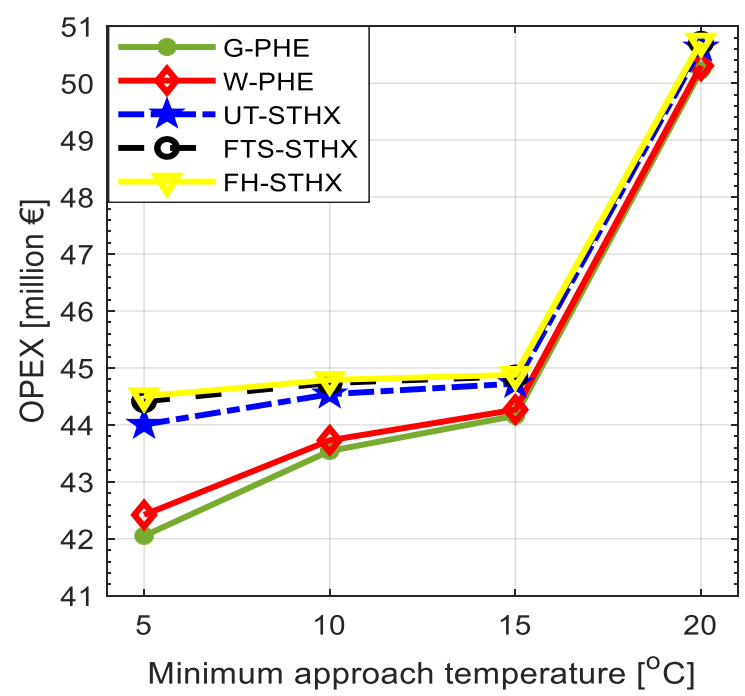

Figure 7. OPEX of the different heat exchangers at different $\Delta T_{\min }$

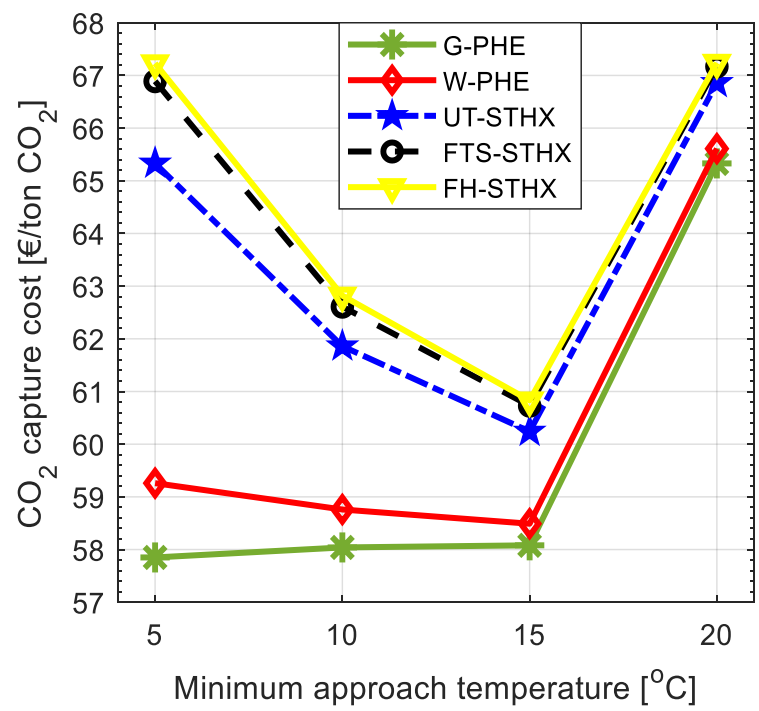

Figure 8. Cost optimum $\Delta T_{\text {min }}$ of the different heat exchangers

Nonetheless, the plate and frame heat exchangers are increasingly being considered for 
application in the process industry (Peters et al., 2004). This is because capital-intensive processes need heat exchangers that can achieve higher thermal efficiencies and simultaneously reducing equipment/investment costs (Peters et al., 2004). The PHEs also occupy less space and have less weight for the same heat transfer area as STHX.

\subsection{Maintenance}

Maintenance of the G-PHE is easier and far less expensive. The plates are removable and can easily be cleaned mechanically. Thus, it is the most ecological option (Marcano, 2015). The parts can easily be replaced relatively inexpensively.

The plates of the W-PHE are welded and thus are not removable. Consequently, cleaning can only be done by chemical means. The only advantage over G-PHE is that W-PHE can withstand higher pressures and temperatures. This advantage is not relevant in $\mathrm{CO}_{2}$ solvent-based absorption and desorption systems since the pressures and temperatures are relatively low

FTS-STHX and FH-STHX are cleaned both mechanically (inside the tubes) and chemically (outside surfaces of tube). The UT-STHX normally requires only chemical cleaning because of the $U$ tube shape of the tubes.

Therefore, the G-PHE which require less space is the most ecologically friendly option, and it is the easiest and the cheapest to maintain among the heat exchangers investigated.

\subsection{Maintenance and Operating Cost Discussion}

Figure 7 presents the OPEX calculated in this study. At $\Delta T_{\min }$ of $5-10^{\circ} \mathrm{C}$, the calculated annual OPEX of the PHEs is considerably less than that of any of the STHXs, even though the difference in this study is only based on maintenance cost. The gap gets closer at $15^{\circ} \mathrm{C}$ and and very close at $20^{\circ} \mathrm{C}$. This is because the purchase and installed costs of the STHXs reduce drastically at $\Delta T_{\min } 15$ and $20^{\circ} \mathrm{C}$.

\subsection{Comparison with Previous Studies}

In this section, comparison of this study is done with some previous studies. All the previous studies used the STHX.

(Øi et al., 2014) calculated the cost optimum $\Delta T_{\min }$ of a plant with 16 absorber packing stages, and 20 years period with discount rate of $10.5 \%$ to be $12^{\circ} \mathrm{C}$.

(Aromada and $\varnothing \mathrm{i}, 2017$ ) estimated it to be $13^{\circ} \mathrm{C}$ for a system with 15 absorber packing stages with discount rate of $7 \%$ for 20 operational years, based on negative-NPV method. When the years of plant operation were reduced to 15 years, cost optimum $\Delta T_{\min }$ became $14^{\circ} \mathrm{C}$.

(Kallevik, 2010), also applied negative NPV for 20 years calculation period, with $7 \%$ discount rate, estimated the cost optimum $\Delta T_{\min }$ to fall within 10 $-14^{\circ} \mathrm{C}$, for a $85 \% \mathrm{CO}_{2}$ capture with 15 absorber packing stages.

Most recent is (Ali et al., 2019), for a calculation period of 24 years and interest rate of $7.5 \%$, evaluated the cost optimum $\Delta T_{\min }$ to be $10^{\circ} \mathrm{C}$.

These results suggest that the cost optimum $\Delta T_{\min }$ for the STHXs is within $10-16^{\circ} \mathrm{C}$, which are in agreement with this study. The little differences obtained from the different studies occur due to the different sources of cost data and economic assumptions like interest rates and operational years.

Several technical studies have also shown that operating at $5^{\circ} \mathrm{C} \Delta T_{\min }$ will help in reduction of the reboiler heat in $\mathrm{CO}_{2}$ capture processes. However, the capital cost of achieving this makes it not to be the cost optimum design parameter for the wellestablished STHX. This study suggests that $\Delta T_{\min }$ of $5^{\circ} \mathrm{C}$ or between $5-10^{\circ} \mathrm{C}$ can be energy optimum and cost optimum design if G-PHE is used.

\section{Conclusion}

Simulations of $85 \% \mathrm{CO}_{2}$ absorption and desorption process aimed at cost optimisation of the lean/rich heat exchanger has been performed using Aspen HYSYS Version 10. This was followed by cost estimation and optimisation of the lean/rich heat exchanger by finding the type of heat exchanger and the design optimum $\Delta T_{\min }$ among $5,10,15$ and $20^{\circ} \mathrm{C} \Delta T_{\min }$. Considerable savings in capital and operating costs can be achieved by selecting the plate and frame heat exchanger instead of the conventional shell and tube types, in a $\mathrm{CO}_{2}$ absorption and desorption plant design. The PHEs require only $30,15,9$, and 6 number of units for the cases of $5,10,15$ and $20^{\circ} \mathrm{C} \Delta T_{\min }$ respectively, compared to $44,23,13,9$ number of units respectively for the STHXs. The G-PHE gives the lowest total annual cost in all the $\Delta T_{\text {min }}$. G-PHE with $5^{\circ} \mathrm{C} \Delta T_{\min }$ is calculated to be the energy optimum and the cost optimum design for the lean/rich heat exchanger.

\footnotetext{
Abbreviations

PHE: $\quad$ Plate and frame heat exchanger

G-PHE: Gasketed-plate or plate and frame heat exchanger

W-PHE: Welded- plate heat exchanger

STHX: Shell and tube heat exchanger

UT-STHX: U-tube shell and tube heat exchanger

FTS-STHX: Fixed-tube sheet Shell and tube heat exchanger

FH-STHX: Floating head shell and tube heat exchanger
} 


\section{References}

H. Ali, N.H. Eldrup, F. Normann, R. Skagestad, and L. E. Øi. Cost Estimation of $\mathrm{CO}_{2}$ Absorption Plants for $\mathrm{CO}_{2}$ Mitigation-Method and Assumptions. International Journal of Greenhouse Gas Control, 88, 10-23, 2019. doi: 10.1016/j.ijggc.2019.05.028

H. Ali, L. E. Øi, and N. H. Eldrup. Simulation and Economic Optimization of Amine-based $\mathrm{CO}_{2}$ Capture using Excess Heat at a Cement Plant Linköping University Electronic Press Conference Proceedings (SIMS 59), 153:58-64, 2018. doi:10.3384/ecp 1815358

S. A. Aromada and L. E. Øi. Simulation of Improved Absorption Configurations for $\mathrm{CO}_{2}$ Capture. Linköping Electronic Press Conference Proceedings (SIMS 56), 119(2):21-29, 2015. doi: 10.3384/ecp1511921

S. A. Aromada and L. E. Øi. Energy and Economic Analysis of Improved Absorption Configurations for $\mathrm{CO}_{2}$ Capture. Energy Procedia, 114: 1342-1351, 2017. doi: $10.1016 /$ j.egypro.2017.03.1900

L. M. Boldon and P. Sabharwall. Small modular reactor: First-of-a-Kind (FOAK) and Nth-of-a-Kind (NOAK) Economic Analysis (No. INL/EXT-14-32616). Idaho National Lab. (INL), Idaho Falls, ID (United States), 2014. doi: $10.2172 / 1167545$

Carbon Capture and Storage Association (Webpage). Affordability, CCS: Keeping the lights on without costing the earth. 2011 - 2020. Available: http://www.ccsassociation.org/whyccs/affordability/ Accessed 07.05.2020

J. Husebye, A. Brunsvold, S. Roussanaly and X. Zhang. Techno economic evaluation of amine based $\mathrm{CO}_{2}$ capture: impact of $\mathrm{CO}_{2}$ concentration and steam supply. Energy Procedia, 23, 381 - 390, 2012. doi: $\underline{10.1016 / j . e g y p r o .2012 .06 .053}$

L. Irlam. Global costs of carbon capture and storage. Global CCS Institute, Melbourne, Australia, 2017.

O. B. Kallevik. Cost estimation of $\mathrm{CO}_{2}$ removal in HYSYS. Master's thesis. Høgskolen i Telemark, 2010.

Y. Lim, J. Kim, J. Jung, C. S. Lee, and C. Han. Modeling and simulation of $\mathrm{CO}_{2}$ capture process for coal-based power plant using amine solvent in South Korea. Energy Procedia, 37:1855-1862, 2013. doi.org/10.1016/j.egypro.2013.06.065

L. A. Marcano. Design and evaluation of heat exchangers used in post-combustion $\mathrm{CO}_{2}$ capture plants. Master's Thesis. Telemark University College, Porsgrunn, 2015.

Norgesbank webpage. Available on: https://www.norges-bank.no Accessed: 25.01.2020.

C. Nwaoha, M. Beaulieu, P. Tontiwachwuthikul and M. D. Gibson. Techno-economic analysis of $\mathrm{CO}_{2}$ capture from a 1.2 million MTPA cement plant using AMPPZ-MEA blend. International Journal of Greenhouse Gas Control, 78:400-412, 2018. doi.org/10.1016/i.ijggc.2018.07.015

K. Onarheim, S.Ò. Garðarsdòttir, A. Mathisen, L. O. Nord and D. Berstad. Industrial implementation of carbon capture in Nordic industry sectors. Nordic CCS Competence Centre NORDICCS 2015.

M. S. Peters, K. D. Timmerhaus, and R. E. West. Plant Design and Economics for Chemical Engineers, $5^{\text {th }}$ edition, McGraw-Hill Companies, Inc. Singapore 2004.

E. S. Rubin, C. Short, G. Booras, J. Davison, C. Ekstrom, M. Matuszewski and S. McCoy. A proposed methodology for $\mathrm{CO}_{2}$ capture and storage cost estimates. International Journal of Greenhouse Gas Control, 17, 488-503, 2013 doi: 10.1016/j.ijggc.2013.06.004

SSB (Norwegian Statistisk sentralbyrå) webpage. Industrial cost index. Available on: https://www.ssb.no/en Accessed 25.01.2020.

M. van der Spek, S. Roussanaly and E. S: Rubin. Best practices and recent advances in CCS cost engineering and economic analysis. International Journal of Greenhouse Gas Control,83:91-104, 2019. doi: 10.1016/j.ijggc.2019.02.006

F. Yu. Process design for chemical engineers. Ten Books, Inc., 2014.

L. E. Øi. Aspen HYSYS simulation of $\mathrm{CO} 2$ removal by amine absorption in a gas based power plant. The 48th Scandinavian Conference on Simulation and Modelling (SIMS 2007), Göteborg, Sweden, Linköping University Electronic Press, 27:73-81, 2007.

L. E. Øi, T. Bråthen, C. Berg, S. K. Brekne, M. Flatin, R. Johnsen, I. G. Moen, and E. Thomassen. Optimization of configurations for amine based $\mathrm{CO}_{2}$ absorption using Aspen HYSYS. Energy Procedia, 51:224-233, $2014 . \quad$ doi: 10.1016/j.egypro.2014.07.026 